\title{
Analýza úrovne silových schopností synchronizovaných plavkýň
}

\section{Analysis of Strength Level Abilities in Synchronized Swimming}

\author{
Jana Labudová, Ivan Matúš
}

Fakulta telesnej výchovy a športu Univerzity Komenského, Bratislava, SR

\begin{abstract}
Abstrakt
Príspevok prezentuje výsledky diagnostiky silových schopností horných končatín synchronizovaných plavkýň sútažiacich vo vekových kategóriách staršich žiačok, junioriek a senioriek. Úroveñ telesného rozvoja posudzovaného podla BMI noriem pre bežnú populáciu odzrkadluje požiadavky športového výko$n u v$ tomto esteticko-koordinačnom športe. Na zistenie úrovne sily a výkonu bol použitý plavecký ergometer (Swimergo). Výsledky meraní preukázali vyrovnanú úroveň silových parametrov v rámci súborov. Štatisticky významný sa prejavil vztah medzi maximálnou silou a výkonom pravej a lavej paže, pričom dominantnejšia sa u všetkých probandiek prejavila pravá paža. Štatisticky významné rozdiely výsledkov medzi skupinami poukázali na vývojové tendencie rastu sily a výkonu počas záberov paží od starších žiačok po juniorky až seniorky.
\end{abstract}

\begin{abstract}
This paper presents the results of the diagnostic strength capabilities of the upper limbs synchronized swimmer competing in two age groups. The level of physical development considered by BMI standards of normal population reflects the requirements of sports in this aesthetic-coordination sport. We have used swimming ergometer (swimergo) to determine the level of strength and performance. Measurement results show a balanced level of strength parameters in the group. Statistically significant relationship between maximum strength and performance of right and left arms, and dominance is reflected in all members in right arm. Statistically significant differences in results between the groups pointed to tendencies of growth strength and performance during arms stroke of the older female pupils to juniors and seniors.
\end{abstract}

Klúčové slová: diagnostika silových schopností, synchronizované plávanie, vekové kategórie, plavecký ergometer

Keywords: $\quad$ diagnostics of strength abilities, synchronized swimming, ages, swimming ergometer

\section{ÚVOD}

Cielom športového výkonu v synchronizovanom plávaní, ktorý má esteticko-koordinačný charakter, je dokonalé vykonanie náročnej pohybovej zostavy pomocou dokonalej techniky. Predstavuje prepojenie plaveckej kompetencie s umeleckými hodnotami baletu, tanca a akrobacie. Získanie optimálnej športovej výkonnosti vyžaduje zvládnutie nielen techniky plaveckých spôsobov a špeciálnu techniku pri vykonávaní predpísaných polôh, obratov a presunov, ale i požadovanú úroveň gymnastických zručností, rytmus, hudobnost a úroveň individuálneho umeleckého prejavu (Labudová, 2009). Na základe celkovej analýzy doterajších výsledkov výskumov v oblasti štruktúry športového výkonu v synchronizovanom plávaní predpokladáme výraznejší vplyv motorických ukazovatelov: vytrvalostné schopnosti, špeciálna vytrvalost', sila končatín a brušného svalstva, kĺbová pohyblivost’ a koordinácia v špecifickom vodnom prostredí (Streitová, 1996; Duvač - Labudová, 2008; Doležajová - Lednický, 2002; Čechovská Peslová, 2007; Labudová - Zemková, 2009). Športový výkon v synchronizovanom plávaní má svoju špecifickú štruktúru a jej diagnostikovanie, analyzovanie a poznanie je základným východiskom pre systematické dlhodobé tréningové a sútažné zatažovanie (Bočkayová - Labudová, 2004). V súlade s názormi Olšák (2006), Ružbarský (2006) má význam využitie športovej diagnostiky nielen pri výbere talentovanej mládeže pre plavecké športy, etapovú diagnostiku trénovanosti, denné posudzovanie stavu organiz- 
mu a jeho reakcie na predchádzajúcu zátaž, ale aj poskytovanie spätnoväzbových informácií vo vlastnom priebehu jednotky zat’aženia, a tým možnost priameho zvyšovania efektivity tréningu.

Silové schopnosti sú základné a rozhodujúce schopnosti človeka, bez ktorých sa nemôžu ostatné pohybové schopnosti prejavit’ a rozvinút. Väčšina autorov Dovalil et al. (2002), Moravec et al. (2004), Kasa $(2002,2006)$ atd'. definujú silu ako schopnost' nervovo-svalového aparátu prostredníctvom svalovej činnosti prekonávat určitý odpor vonkajšieho prostredia. Na posudzovanie úrovne silových schopností boli vytvorené unifikované testové batérie Eurofit a Unifittest (6-60), ktoré sú postačujúce pre stredné školy a bežnú populáciu (Moravec - Kampmiller - Sedláček et al., 1996).

Pre potreby diagnostiky silových schopností vo výkonnostnom a vrcholovom plávaní boli skonštruované rôzne plavecké pomôcky na suchu ako aj vo vode (biokinetická lavica, ergometre, tenzometre, pružné závesy atd'). Novšie technologické postupy v testovaní sily u plavcov nám umožňujú zistit maximálnu produkovanú silu v deltovom svale počas aktivít, ktoré skoro presne napodobňujú pohyby používané v plávaní. Napr. izokinetický prístroj - biokinetická plavecká lavica BiokineticTM (Richmond, California) je schopná testovat plaveckú silu, poskytuje možnost napodobňovat pohyb v ramenom kíbe počas motýlikového a kraulového záberu. Vývoje systémov výstupných počítačových báz merajúcich silu a výkon počas cvičenia sa snažia o citlivé a spolahlivé výsledky stanovenia svalového výkonu počas vykonávania cvičenia (Costil - Maglischo -Richardson, 1992). Firma WEBA sport skonštruovala plavecký ergometer - Swim ergometer, ktorý slúži pre potreby plavcov, vie simulovat plavecký pohyb a zároveň umožňuje meranie a následné diagnostikovanie nameraných výsledkov. Prístroje na diagnostiku silových schopností v plávaní, ale aj v iných športoch sa stávajú neodmyslitelnou súčastou každého trénovania, ako aj vo výskume pri zistovaní svalovej činnosti pri maximálnych zataženiach rýchlostne-silového charakteru (Matúš - Macejková, 2009).

Pri aplikácií plaveckého ergometra u synchronizovaných plavkýň vychádzame z analogickej trajektórie záberov paží počas realizácie športového výkonu ako v plávaní. Výskum sa realizoval v rámci grantovej úlohy VEGA č. 1/0674/08.

\section{CIEL' PRÁCE}

Cielom práce bolo diagnostikovat úroveň silových schopností paží počas imitovaného prsiarskeho záberu a počas imitovaného záberu pri výpichu (trčenie). Oba typy záberov sa priamo vyskytujú v športovom výkone v synchronizovanom plávaní. Porovnaním zistených výsledkov u mladšej a staršej vekovej kategórie poukázat’ na vývojové tendencie rastu sily a výkonu paží, súvisiace s ontogenézou a dížkou športovej prípravy.

\section{METODIKA}

Súbor tvorilo 21 synchronizovaných plavkýň (Tab. 1). V staršej vekovej kategórii bolo zaradených 10 senioriek a junioriek vo veku od 16 - 20 rokov (1. skupina) a v mladšej vekovej kategórii 11 starších žiačok vo veku od 12 - 15 rokov (2. skupina). Pretekárky sa zúčastňujú na významných domácich aj zahraničných podujatiach ako sú Majstrovstvá Slovenskej a Českej republiky a 8 juniorských reprezentantiek sútažilo v roku 2009 na Majstrovstvách Európy.

Tabulka 1 Základná charakteristika súboru

\begin{tabular}{|c|c|c|c|c|c|c|}
\hline \multicolumn{4}{|c|}{ 1. skupina - Seniorky a juniorky $(\mathrm{n}=10)$} & \multicolumn{3}{|c|}{ 2. skupina - Staršie žiačky $(\mathrm{n}=11)$} \\
\hline & $\begin{array}{c}\text { Stature } \\
(\mathrm{cm})\end{array}$ & $\begin{array}{c}\text { Body } \\
\text { weight }(\mathrm{kg})\end{array}$ & BMI & $\begin{array}{c}\text { Stature } \\
(\mathrm{cm})\end{array}$ & $\begin{array}{c}\text { Body } \\
\text { weight }(\mathrm{kg})\end{array}$ & BMI \\
\hline $\begin{array}{l}\text { arithmetic } \\
\text { average }\end{array}$ & 171,2 & 56,6 & 19,285 & 161,64 & 48,36 & 18,38 \\
\hline $\begin{array}{l}\text { standard } \\
\text { deviation }\end{array}$ & 4,3919 & 5,1034 & 1,2508 & 7,6456 & 8,3579 & 1,8306 \\
\hline min. & 163 & 46 & 17,313 & 151 & 36 & 15,789 \\
\hline $\max$. & 180 & 63 & 20,809 & 171 & 61 & 20,861 \\
\hline
\end{tabular}


Testovanie prebiehalo na FTVŠ UK v Bratislave v roku 2009, v prípravnom období zimnej sezóny ročného tréningového cyklu, v mesiaci november. Súbor sa po štandardnom rozcvičení podrobil testovaniu. Monitorovanie silových schopností paží bolo realizované na plaveckom ergometri Swimergo. Na registrovanie silových schopností sme použili dva testy.

Prvý test spočíval v monitorovaní silových parametrov po dobu 10 sekúnd, kde probandky imitovali prsiarsky záber. Probandka ležala na lavici v polohe na prsiach, hornými končatinami k prístroju. Na zvukový signál začala tahat' lanko ergometra synchrónne obidvoma pažami zo vzpaženia smerom dozadu (imitácia prsiarskeho záberu vo vode) po dobu 10 sekúnd. Všetky probandky absolvovali 2 opakovania s intervalom odpočinku 4 min.

$\mathrm{V}$ druhom teste sme registrovali rovnaké parametre sily počas troch záberov paží, ktoré imitovali pohyby počas trčenia (výpichu). Tento typ záberov paží aplikujú pretekárky počas vykonania niektorých povinných figúr a v sútažných zostavách. Probandka ležala na chrbte dolnými končatinami k prístroju. Paže sa nachádzali pri tele a na znamenie smerovali cez upaženie do vzpaženia a spät. Všetky probandky absolvovali podobne ako v prvom testovaní 2 opakovania s intervalom odpočinku 4 minúty.

$\mathrm{Na}$ získanie výskumných dát bol použitý plavecký ergometer Swimergo (Obr.1). Je to produkt firmy Weba sport, ktorý umožňuje plavcovi simulovat plavecký pohyb na suchu. Umožňuje zvýšit a zlepšit pevnost' a pružnost' hornej časti tela a dokáže monitorovat' pohyb pravej a lavej paže pri imitácií rôznych plaveckých spôsobov na tomto prístroji.

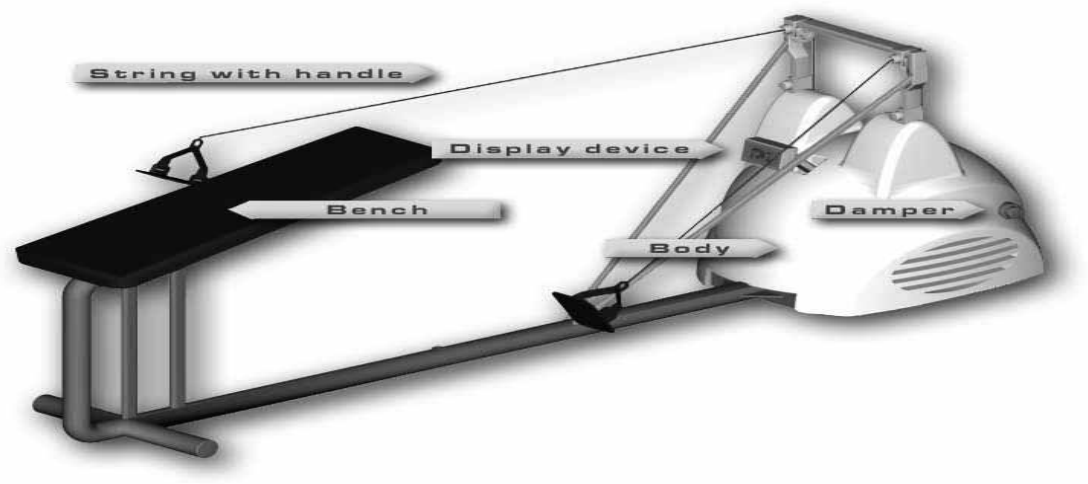

Obrázok 1 Plavecký ergometer Swimergo

Vonkajšia čast’ sa skladá z kovovej konštrukcie, plastového krytu a displeja. Na kovovej konštrukcii sú upevnené kladky s lankami, na konci ktorých sú pripevnené "packy", ktoré si plavec natiahne na ruky pred cvičením. Druhý koniec laniek vedie do prístroja na navíjače. Systém kladiek umožňuje predozadný pohyb, ale taktiež pohyb do strán. Senzory, ktoré sa nachádzajú vo vnútri prístroja na navíjačoch cez káble, prenášajú údaje na displej, ktorý sa nachádza nad prístrojom. Plavec môže na displeji v priebehu cvičenia vizuálne kontrolovat zábery. Vo vnútornej časti prístroja sa nachádza odporová turbína s regulátorom, ktorá je poháňaná silou tahania. Turbína sa dá otvorit alebo zatvorit', čím dosiahneme konštantný odpor. Pri otvorenej turbíne kladie prístroj väčší odpor. Cez turbínu prechádza hriadel', na ktorom sa nachádzajú navíjacie systémy, ktoré majú vlastné nezávislé senzory. Lanká sa pri potiahnutí odvíjajú a pri uvol’není naspät navíjajú. Aby bola zabezpečená stálost' tahania, vo vnútri sa nachádza systém kladiek prepojených elastickým lankom, ktoré zabezpečujú spätné navinutie. Druhá čast̉ prístroja sa skladá z kovovej konštrukcie s doskou, na ktorej plavec počas cvičenia leží. Zaznamenané údaje sa prenášajú do počítača, ktoré spracuje a vyhodnotí program Weba expert. Zoznam sledovaných ukazovatelov uvádza tabulka 2. 
Tabulka 2 Sledované ukazovatele

\begin{tabular}{|l|l|}
\hline BMI & index telesnej hmotnosti \\
\hline Left arm & l'avá paža \\
\hline Right arm & pravá paža \\
\hline Force avr. [N] & priemerná sila počas záberu \\
\hline Force max. [N] & maximálna sila počas záberu \\
\hline Power avr. [W] & priemerný výkon počas záberu \\
\hline Power max. [W] & maximálny výkon počas počas záberu \\
\hline Force 1 avr. [N] & priemerná sila l'avej paže počas záberu \\
\hline Force 1 max. [N] & maximálna sila l'avej paže počas záberu \\
\hline Power 1 avr. [W] & priemerný výkon l'avej paže počas záberu \\
\hline Power 1 max. [W] & maximálny výkon l'avej paže počas záberu \\
\hline Stroke lenght 1 avr. (cm) & priemerná dĺžka záberu l'avej paže počas záberu \\
\hline Force 2 avr. [N] & priemerná sila pravej paže počas záberu \\
\hline Force 2 max. [N] & maximálna sila pravej paže počas záberu \\
\hline Power 2 avr. [W] & priemerný výkon pravej paže počas záberu \\
\hline Power 2 max. [W] & maximálny výkon pravej paže počas počas záberu \\
\hline Stroke lenght 2 avr. (cm) & priemerná dížka záberu pravej paže počas záberu \\
\hline Arithmetic average & aritmetický priemer \\
\hline Standard deviation & smerodajná odchýlka \\
\hline Var. & variačné rozpätie \\
\hline Min. & minimum \\
\hline Max. & maximum \\
\hline
\end{tabular}

Na vyhodnotenie výsledkov meraní sme použili matematicko-štatistické a logické metódy. Na zistenie úrovne štatistickej významnosti vztahov medzi sledovanými ukazovatelmi sme použili neparametrický Wicoxonov T-test. Závislost’ medzi sledovanými skupinami sme vyhodnocovali neparametrickým Mann-Whitneyovým U-testom.

\section{VÝSLEDKY A DISKUSIA}

Z hladiska úrovne telesného rozvoja (Tab. 1) konštatujeme, že priemerná výška prvej skupiny probandiek bola $171,2 \mathrm{~cm}$, čo je o 9,56 cm viac ako u druhej skupiny probandiek $(161,6 \mathrm{~cm})$. Rozdiel v priemernej telesnej hmotnosti medzi prvou a druhou skupinou bol 8,24 kg. Pri posúdení priemerných hodnôt BMI (Body Mass Index) sme u starších žiačok zistili 18,38 čo je o 0,81 lepšia priemerná hodnota v porovnaní s juniorkami a seniorkami. Podla noriem pre bežnú populáciu sa probandky pohybujú v norme až v miernej podvýžive, čo odzrkadluje požiadavky športového výkonu v tomto esteticko-koordinačnom športe.

V prvom teste prvej skupiny probandiek (juniorky a seniorky) zo získaných výsledkov silových schopností paží konštatujeme vyrovnanú úroveň súboru (Tab. 3). Priemerná dľžka záberu l’avej paže počas $10 \mathrm{~s}$ imitovania prsiarskeho záberu bola v prvej skupine $122,7 \mathrm{~cm}$, pričom najvyššiu priemernú hodnotu dosiahla probandka K.K. $(133 \mathrm{~cm})$. Priemerná dĺžka záberu pravej paže počas $10 \mathrm{~s} \mathrm{v} \mathrm{pr-}$ vej skupine bola $123,1 \mathrm{~cm}$, pričom najvyššiu priemernú hodnotu dosiahla opät probandka K.K. (134 $\mathrm{cm})$. Pri porovnaní priemerných dĺžok záberu konštatujeme dlhšiu dráhu pravej paže. Prvá skupina dosiahla priemernú silu záberu l’avou pažou $44,2 \mathrm{~N}$, pričom maximálna sila lavej paže predstavovala 51,9 N. Priemerná sila záberu pravou pažou $49,6 \mathrm{~N}$, pričom maximálna sila pravej paže predstavovala $58 \mathrm{~N}$. Dosiahnutý priemerný výkon lavej paže počas $10 \mathrm{~s}$ intervalu bol v prvej skupine 50,2 
W, u pravej paže bola hodnota 61,5 W. Maximálny výkon zaregistrovaný lavou pažou predstavoval $55,6 \mathrm{~W}$ a pravou $67,9 \mathrm{~W}$. Je potrebné poznamenat, že výkon charakterizuje vykonanú prácu za časovú jednotku. V našom prípade probandky pôsobili silou horných končatín (F) na tahadlo prístroja (teleso) a premiestňovali ho po dráhe (s) v smere pôsobiacej sily - smerom vzad. Zistený výkon (fyzikálna veličina) teda poukazuje na to, ako rýchlo danú prácu vykonali. Zistené výsledky prezentujú u probandiek dominanciu pravej paže jednak z hladiska sily záberu, ako aj z hladiska výkonu. Napriek tomu, že probandky B.D. a S.A. nevykonali najdlhší záber, zaregistrovali sme u nich najvyššie hodnoty priemernej a maximálnej sily a výkonu počas záberov oboch paží. Uvedené zistenie poukazuje na priebeh sily počas záberu, ktorý narastá s dížkou záberu, kde sila dosiahne maximálne hodnoty skôr ako je ukončená dráha pohybu (Obr.2).

Pri celej súhre (test 1) sme v prvej skupine namerali hodnoty priemernej sily - 93,9 N, pričom najvyššiu hodnotu zo sledovaného súboru sme zaznamenali probandke M. L., ktorej priemerná sila lavej paže bola 103 N. Maximálna sila dosiahnutá pri imitácií prsiarskeho záberu v sledovanom súbore mala hodnotu 110,2 N. Najvyššiu maximálnu silu počas 10 sekúnd testovania sme zaregistrovali probandke S. A. (120 N). Priemerný výkon prvej skupiny v súhre bol 111,6 W a maximálny 123,2 W. Podobne ako pri sile najvyššie hodnoty priemerného 137 W, ale aj maximálneho 145 W výkonu dosiahla probandka M.L.

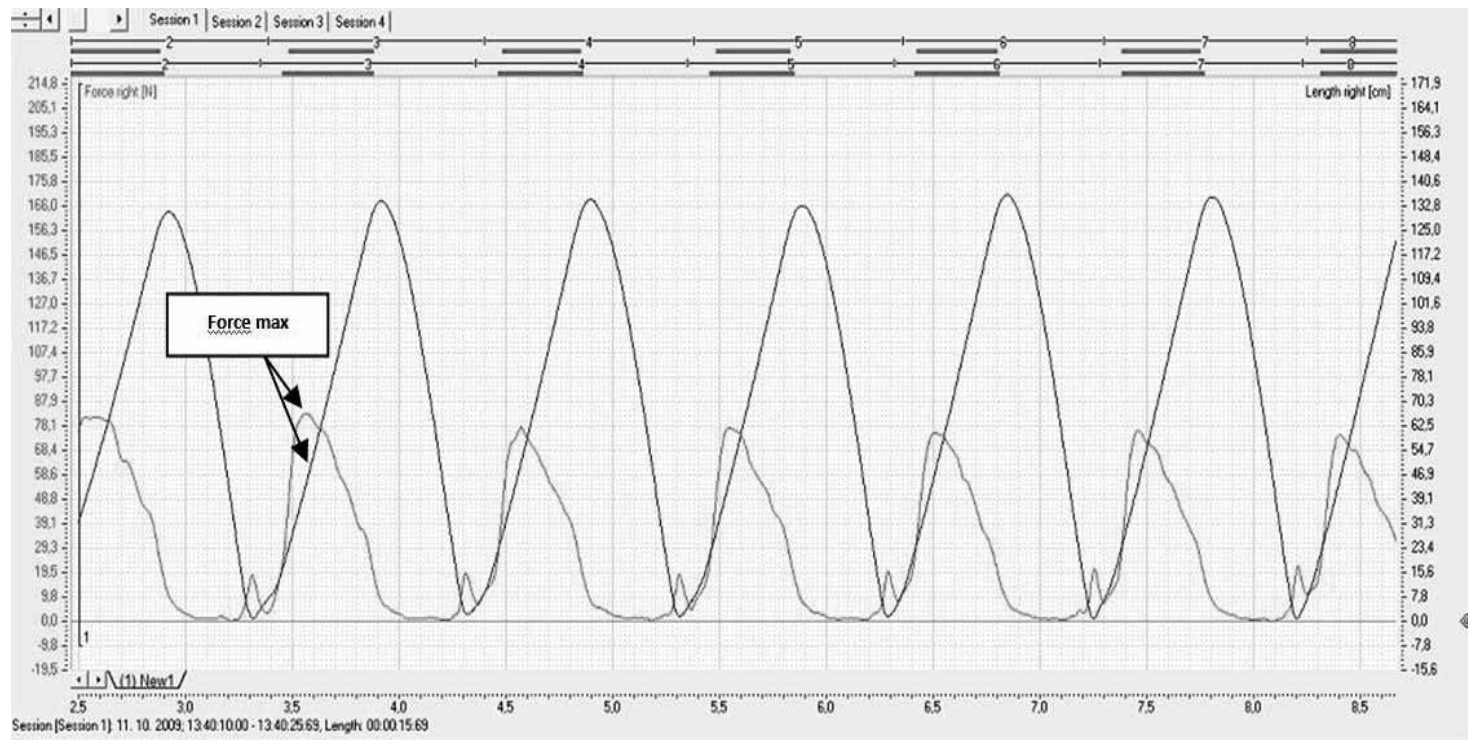

Obrázok 2 Priebeh dížky a sily záberu pravej paže u probandky B.D. (test 1)

Na základe vyhodnotenia vztahov medzi sledovanými ukazovatelmi v 1 . skupine probandiek v teste 1 konštatujeme tesnú závislost priemerných a maximálnych hodnôt sily a výkonu, ktorá sa prejavila na $1 \%$ hladine štatistickej významnosti (Tab. 4). 
Tabulkka 3 Matematicko-štatistická charakteristika výsledkov 1. skupiny (test 1)

\begin{tabular}{|c|c|c|c|c|c|c|c|c|c|c|c|c|c|c|}
\hline & \multirow{2}{*}{\multicolumn{2}{|c|}{ Force $(\mathbf{N})$}} & \multirow{2}{*}{\multicolumn{2}{|c|}{ Power (W) }} & \multicolumn{5}{|c|}{ Left arm } & \multicolumn{5}{|c|}{ Right arm } \\
\hline & & & & & \multirow{2}{*}{$\begin{array}{l}\text { Stroke } \\
\text { Lenght } \\
\text { avr.(cm) }\end{array}$} & \multicolumn{2}{|c|}{ Force $1(\mathrm{~N})$} & \multicolumn{2}{|c|}{ Power 1 (W) } & \multirow{2}{*}{$\begin{array}{c}\text { Stroke } \\
\text { Lenght } \\
\text { avr.(cm) }\end{array}$} & \multicolumn{2}{|c|}{ Force $2(\mathrm{~N})$} & \multicolumn{2}{|c|}{ Power $2(\mathrm{~W})$} \\
\hline & avr. & max. & avr. & $\max$ & & avr. & max. & avr. & max. & & avr. & $\max$ & avr. & max. \\
\hline $\begin{array}{l}\text { arithmetic } \\
\text { average }\end{array}$ & 93,90 & 110,20 & 111,60 & 123,20 & 122,70 & 44,20 & 51,90 & 50,20 & 55,60 & 123,10 & 49,60 & 58,00 & 61,50 & 67,90 \\
\hline $\begin{array}{l}\text { standard } \\
\text { deviation }\end{array}$ & 6,15 & 7,38 & 15,29 & 16,44 & 6,24 & 2,15 & 3,00 & 6,86 & 7,31 & 7,26 & 4,38 & 4,50 & 8,78 & 9,45 \\
\hline median & 95,50 & 111,00 & 113,00 & 125,50 & 121,00 & 44,50 & 53,50 & 51,00 & 57,00 & 121,00 & 51,00 & 58,00 & 62,00 & 68,50 \\
\hline min. & 83,00 & 97,00 & 90,00 & 96,00 & 112,00 & 41,00 & 47,00 & 41,00 & 43,00 & 111,00 & 42,00 & 50,00 & 49,00 & 53,00 \\
\hline $\max$. & 103,00 & 120,00 & 137,00 & 145,00 & 133,00 & 47,00 & 55,00 & 60,00 & 65,00 & 134,00 & 56,00 & 65,00 & 77,00 & 81,00 \\
\hline var. & 20,00 & 23,00 & 47,00 & 49,00 & 21,00 & 6,00 & 8,00 & 19,00 & 22,00 & 23,00 & 14,00 & 15,00 & 28,00 & 28,00 \\
\hline
\end{tabular}

Tabul'ka 4 Neparametrický Wilcoxonov T-test 1. skupina (test 1)

\begin{tabular}{|l|l|c|c|}
\hline \multicolumn{2}{|l|}{} & T - test & Sign. \\
\hline & avr. & 0,490 & \\
\hline Force & avr. & $\mathbf{2 , 7 5 2}^{* *}$ & $\mathrm{p}<0,01$ \\
\hline & max. & $\mathbf{2 , 7 5 2}^{* *}$ & $\mathrm{p}<0,01$ \\
\hline Power & avr. & $\mathbf{2 , 7 5 2 * *}$ & $\mathrm{p}<0,01$ \\
\hline & max. & $\mathbf{2 , 7 5 2}$ & \\
\end{tabular}

V druhej skupine (staršie žiačky) z nameraných výsledkov silových parametrov sme zaregistrovali taktiež vyrovnanú úroveň súboru. Výsledky nám poukazujú na fakt, že aj v tomto súbore je dominantnejšia pravá paža, kde sme zistili dlhšiu dráhu záberu, vyššie hodnoty priemernej a maximálnej sily a výkonu pri záberoch počas $10 \mathrm{~s}$. Priemerná dížka záberu pravej paže bola 118,36 cm a najdlhšiu dráhu záberu sme zaregistrovali u probandky Ac. L. $(129 \mathrm{~cm})$. Priemerná dĺžka záberu lavej paže bola 117,36 $\mathrm{cm}$. Podobne ako pri pravej paži tak aj pri lavej sme zaznamenali najdlhšiu dráhu záberu probandke Ac. L. $(128 \mathrm{~cm})$. Pri dominantnejšej pravej paži sme v druhej skupine namerali vyššie hodnoty priemernej $(45,09 \mathrm{~N})$ a maximálnej $(48,64 \mathrm{~N})$ sily oproti hodnotám priemernej $(40,73 \mathrm{~N})$ a maximálnej $(44 \mathrm{~N})$ sily registrovanej lavou pažou. Priemerný výkon pravej paže v súbore bol 45,5 W a maximálny 48,64 W. Kedže lavá paža bol slabšia, vyprodukovala aj menší výkon, kde priemerný výkon lavej paže v súbore bol 37,09 W a maximálny výkon bol 42,27 W. Najvyššie hodnoty priemernej a maximálnej sily a výkonu v druhej skupine sme zaznamenali u probandky s najdlhšou dĺžkou záberu (Tab. 5).

Tabul'ka 5 Matematicko-štatistická charakteristika výsledkov 2. skupiny (test 1)

\begin{tabular}{|c|c|c|c|c|c|c|c|c|c|c|c|c|c|c|}
\hline & \multirow{2}{*}{\multicolumn{2}{|c|}{ Force $(\mathrm{N})$}} & \multirow{2}{*}{\multicolumn{2}{|c|}{ Power (W) }} & \multicolumn{5}{|c|}{ Left arm } & \multicolumn{5}{|c|}{ Right arm } \\
\hline & & & & & \multirow{2}{*}{$\begin{array}{c}\text { Stroke } \\
\text { Lenght } \\
\text { avr.(cm) }\end{array}$} & \multicolumn{2}{|c|}{ Force $1(\mathrm{~N})$} & \multicolumn{2}{|c|}{ Power $1(\mathrm{~W})$} & \multirow{2}{*}{$\begin{array}{c}\text { Stroke } \\
\text { Lenght } \\
\text { avr.(cm) }\end{array}$} & \multicolumn{2}{|c|}{ Force $2(\mathrm{~N})$} & \multicolumn{2}{|c|}{ Power 2 (W) } \\
\hline & avr. & $\max$. & avr. & max. & & avr. & max. & avr. & $\max$ & & avr. & max. & avr. & max. \\
\hline $\begin{array}{l}\text { arithme tic } \\
\text { average }\end{array}$ & 86,36 & 92,55 & 83,00 & 93,73 & 117,36 & 40,73 & 44,00 & 37,09 & 42,27 & 118,36 & 45,09 & 48,64 & 45,55 & 50,45 \\
\hline $\begin{array}{l}\text { standard } \\
\text { deviation }\end{array}$ & 12,82 & 12,80 & 14,16 & 17,40 & 5,43 & 5,87 & 6,00 & 6,06 & 7,99 & 5,92 & 7,27 & 6,99 & 8,10 & 9,16 \\
\hline median & 87,00 & 94,00 & 82,00 & 97,00 & 116,00 & 40,00 & 44,00 & 38,00 & 43,00 & 118,00 & 43,00 & 49,00 & 44,00 & 49,00 \\
\hline min. & 71,00 & 77,00 & 62,00 & 69,00 & 110,00 & 34,00 & 36,00 & 29,00 & 31,00 & 111,00 & 37,00 & 40,00 & 34,00 & 37,00 \\
\hline max. & 113,00 & 119,00 & 108,00 & 124,00 & 128,00 & 53,00 & 55,00 & 48,00 & 59,00 & 129,00 & 60,00 & 64,00 & 60,00 & 63,00 \\
\hline var. & 42,00 & 42,00 & 46,00 & 55,00 & 18,00 & 19,00 & 19,00 & 19,00 & 28,00 & 18,00 & 23,00 & 24,00 & 26,00 & 26,00 \\
\hline
\end{tabular}

Druhej skupine sme pri celkovej súhre záberov paží zaznamenali priemernú silu 86,36 N a maximálnu silu 92,55 N. Priemerný výkon mal hodnotu 83 W a maximálny 93,37 W. Najvyššie hodnoty priemer- 
nej $(113 \mathrm{~N})$ a maximálnej $(119 \mathrm{~N})$ sily, ale aj priemerného (108 W) a maximálneho (112 W) výkonu v celej súhre sme zaregistrovali probandke (Ac.L.), ktorá mala aj najvyššie hodnoty silových schopností pravej a lavej paže. Na základe vyhodnotenia vztahov medzi sledovanými ukazovatelmi $\mathrm{v} 2$. skupine probandiek $\mathrm{v}$ teste 1 konštatujeme tesné závislosti priemerných a maximálnych hodnôt sily a výkonu, ktorá sa prejavila na $1 \%$ hladine štatistickej významnosti (Tab. 6).

Tabulka 6 Neparametrický Wilcoxonov T-test 2. skupina (test 1)

\begin{tabular}{|l|l|c|c|}
\hline \multicolumn{2}{|l|}{} & T - test & Sign. \\
\hline & avr. & 1,580 & \\
\hline Force & avr. & $\mathbf{2 , 8 0 1 ^ { * * }}$ & $\mathrm{p}<0,01$ \\
\hline & max. & $\mathbf{2 , 7 1 2 ^ { * * }}$ & $\mathrm{p}<0,01$ \\
\hline Power & avr. & $\mathbf{2 , 8 9 0 ^ { * * }}$ & $\mathrm{p}<0,01$ \\
\hline & max. & $\mathbf{2 , 8 9 0 ^ { * * }}$ & $\mathrm{p}<0,01$ \\
\hline
\end{tabular}

Na základe zistených výsledkov na plaveckom ergometri môžeme konštatovat', že probandky vekovej kategórie juniorky a seniorky dosiahli podla očakávania vo všetkých sledovaných ukazovatelov v teste 1 lepšie výsledky ako probandky vo vekovej kategórii staršie žiačky. Porovnaním výsledkov oboch skupín môžeme konštatovat závislost väčšiny sledovaných ukazovatelov na $1 \%$ hladine štatistickej významnosti (Tab. 7).

Tabulka 7 Neparametrický Mann-Whitneyov U-test (test 1)

\begin{tabular}{|c|c|c|c|c|c|c|c|c|c|c|c|c|c|}
\hline & \multirow{3}{*}{ Stature } & \multirow{3}{*}{$\begin{array}{c}\text { Body } \\
\text { Weight }\end{array}$} & \multirow{3}{*}{ BMI } & \multicolumn{5}{|c|}{ Left arm } & \multicolumn{5}{|c|}{ Right arm } \\
\hline & & & & \multirow{2}{*}{$\begin{array}{c}\text { Stroke } \\
\text { Lenght } \\
\text { avr.(cm) }\end{array}$} & \multicolumn{2}{|c|}{ Force $1[\mathrm{~N}]$} & \multicolumn{2}{|c|}{ Power 1 [W] } & \multirow{2}{*}{$\begin{array}{c}\text { Stroke } \\
\text { Lenght } \\
\text { avr.(cm) }\end{array}$} & \multicolumn{2}{|c|}{ Force $2[\mathrm{~N}]$} & \multicolumn{2}{|c|}{ Power 2 [W] } \\
\hline & & & & & avr. & max. & avr. & max. & & avr. & max. & avr. & max. \\
\hline Test & $2,766 * *$ & $2,227 *$ & 1,303 & $1,942(*)$ & $1,843(*)$ & $2,731 * *$ & $3,248 * *$ & $2,896 * *$ & $1,776(*)$ & $1,732(*)$ & $2,892 * *$ & $3,171 * *$ & $3,103 * *$ \\
\hline & $p<0,01$ & $p<0,05$ & & $p<0,10$ & $p<0,10$ & $p<0,01$ & $p<0,01$ & $p<0,01$ & $p<0,10$ & $p<0,10$ & $p<0,01$ & $p<0,01$ & $p<0,01$ \\
\hline
\end{tabular}

V druhom teste prvej skupiny probandiek (juniorky a seniorky) zo získaných výsledkov silových schopností paží konštatujeme vyrovnanú úroveň súboru (Tab. 8). Priemerná dížka záberu lavej paže počas imitovania záberov pri výpichu bola v prvej skupine $125,1 \mathrm{~cm}$, pričom najvyššiu priemernú hodnotu dosiahla probandka M.L. (144 cm). Priemerná dľžka záberu pravej paže počas imitovania záberov pri výpichu bola $124 \mathrm{~cm}$, pričom najvyššiu priemernú hodnotu dosiahla opät probandka M.L. $(137 \mathrm{~cm})$. Pri porovnaní priemerných dĺžok záberu konštatujeme dlhšiu dráhu lavej paže. Prvá skupina dosiahla priemernú silu záberu lavou pažou $40 \mathrm{~N}$, pričom maximálna sila lavej paže predstavovala $39,8 \mathrm{~N}$. Priemerná sila záberu pravou pažou 40,6 N, pričom maximálna sila pravej paže predstavovala 41,8 N. Dosiahnutý priemerný výkon lavej paže bol 31,7 W, u pravej paže bola hodnota 38,1 W. Maximálny výkon zaregistrovaný lavou pažou predstavoval $32,5 \mathrm{~W}$ a pravou $39,2 \mathrm{~W}$.

Zistené výsledky v druhom teste poukazujú u probandiek na dominanciu pravej paže jednak z hladiska sily záberu, ako aj z hladiska výkonu. Pri celej súhre (test 2) sme v prvej skupine namerali hodnoty priemernej sily 79,4 $\mathrm{N}$ pričom najvyššiu hodnotu zo sledovaného súboru sme zaznamenali probandke B.D (94 N). Priemerný výkon prvej skupiny v súhre bol 69,7 W a maximálny výkon dosiahla H.P. (82 W). Výsledky testu $2 \mathrm{v}$ prvej skupine probandiek uvádza tabulka 8 . Na základe vyhodnotenia vztahov medzi sledovanými ukazovatelmi $v 1$. skupine probandiek v teste 2 konštatujeme tesnú závislost’ priemerných a maximálnych hodnôt výkonu, ktorá sa prejavila na 1\% hladine štatistickej významnosti (Tab. 9). 
Tabulka 8 Matematicko-štatistická charakteristika výsledkov 1. skupiny (test 2)

\begin{tabular}{|c|c|c|c|c|c|c|c|c|c|c|c|c|c|c|}
\hline & \multirow{2}{*}{\multicolumn{2}{|c|}{ Force $[N]$}} & \multirow{2}{*}{\multicolumn{2}{|c|}{ Power [W] }} & \multicolumn{5}{|c|}{ Left arm } & \multicolumn{5}{|c|}{ Right arm } \\
\hline & & & & & \multirow{2}{*}{$\begin{array}{c}\text { Stroke } \\
\text { lenght } \\
\text { avr.(cm) }\end{array}$} & \multicolumn{2}{|c|}{ Force 1 [N] } & \multicolumn{2}{|c|}{ Power 1 [W] } & \multirow{2}{*}{$\begin{array}{l}\text { Stroke } \\
\text { lenght } \\
\text { avr.(cm) }\end{array}$} & \multicolumn{2}{|c|}{ Force 2 [N] } & \multicolumn{2}{|c|}{ Power 2 [W] } \\
\hline & avr. & max. & avr. & max. & & avr. & max. & avr. & max. & & avr. & max. & avr. & max. \\
\hline $\begin{array}{l}\text { arithmetic } \\
\text { average }\end{array}$ & 79,40 & 81,70 & 69,70 & 71,70 & 125,10 & 40,00 & 39,80 & 31,70 & 32,50 & 124,00 & 40,60 & 41,80 & 38,10 & 39,20 \\
\hline $\begin{array}{l}\text { standard } \\
\text { deviation }\end{array}$ & 7,52 & 8,12 & 7,15 & 6,40 & 8,85 & 5,83 & 4,52 & 3,06 & 3,10 & 8,12 & 3,72 & 4,05 & 4,31 & 4,05 \\
\hline median & 79,50 & 81,50 & 70,50 & 72,00 & 125,50 & 39,00 & 39,50 & 32,00 & 32,50 & 125,00 & 41,00 & 42,00 & 38,50 & 39,50 \\
\hline min. & 68,00 & 70,00 & 56,00 & 59,00 & 111,00 & 34,00 & 34,00 & 26,00 & 27,00 & 108,00 & 34,00 & 35,00 & 30,00 & 32,00 \\
\hline max. & 94,00 & 98,00 & 80,00 & 82,00 & 144,00 & 52,00 & 48,00 & 36,00 & 38,00 & 137,00 & 48,00 & 50,00 & 44,00 & 45,00 \\
\hline var. & 26,00 & 28,00 & 24,00 & 23,00 & 33,00 & 18,00 & 14,00 & 10,00 & 11,00 & 29,00 & 14,00 & 15,00 & 14,00 & 13,00 \\
\hline
\end{tabular}

Tabulka 9 Neparametrický Wilcoxonov T-test 1. skupina (test 2)

\begin{tabular}{|c|c|c|c|}
\hline & & $T-$ test & Sign. \\
\hline & avr. & 1,066 & \\
\hline Force & avr. & 0,829 & \\
\hline & max. & $2,141^{*}$ & $p<0,05$ \\
\hline Power & avr. & $2,752^{\star *}$ & $p<0,01$ \\
\hline & max. & $2,752^{\star *}$ & $p<0,01$ \\
\hline
\end{tabular}

V druhej skupine (staršie žiačky) z nameraných výsledkov silových parametrov sme zaregistrovali taktiež vyrovnanú úroveň súboru. Výsledky nám poukazujú na fakt, že v tomto súbore je dominantnejšia pravá paža, kde sme zistili dlhšiu dráhu záberu, vyššie hodnoty priemernej a maximálnej sily a výkonu pri záberoch počas imitácie záberov pri výpichu. Priemerná dľžka záberu lavej paže bola 116,73 cm a najdlhšiu dráhu záberu sme zaregistrovali u probandky Ac. L. $(127 \mathrm{~cm})$. Priemerná dĺžka záberu pravej paže bola 117,45 cm. Podobne ako pri lavej paži tak aj pri pravej sme zaznamenali najdlhšiu dráhu záberu probandke Ac. L. $(128 \mathrm{~cm})$. Pri dominantnejšej pravej paži sme v druhej skupine namerali vyššie hodnoty priemernej $(33,55 \mathrm{~N})$ a maximálnej $(33,82 \mathrm{~N})$ sily oproti hodnotám priemernej $(29,27 \mathrm{~N})$ a maximálnej $(29,73 \mathrm{~N})$ sily registrovanej lavou pažou. Priemerný výkon pravej paže v súbore bol 33,91 W a maximálny $34,73 \mathrm{~W}$.

Kedže lavá paža bol slabšia, vyprodukovala aj menší výkon, kde priemerný výkon lavej paže v súbore bol 25,82 W a maximálny výkon bol 26,09 W. Najvyššie hodnoty priemernej a maximálnej sily a výkonu v druhej skupine sme zaznamenali u probandky s najdlhšou dĺžkou záberu (Tab. 10). Pri celej súhre sme zaznamenali priemernú silu 62,73 N a maximálnu silu 63,18 N. Priemerný výkon mal hodnotu 59,91 W a maximálny $60,73 \mathrm{~W}$. Najvyššie hodnoty priemernej a maximálnej sily, ale aj priemerného a maximálneho výkonu v celej súhre sme zaregistrovali probandke (Ac.L.), ktorá mala najvyššie hodnoty silových schopností pravej a lavej paže.

Tabul'ka 10 Matematicko-štatistická charakteristika výsledkov 2. skupiny (test 2)

\begin{tabular}{|c|c|c|c|c|c|c|c|c|c|c|c|c|c|c|}
\hline & \multirow{2}{*}{\multicolumn{2}{|c|}{ Force [N] }} & \multirow{2}{*}{\multicolumn{2}{|c|}{ Power [W] }} & \multicolumn{5}{|c|}{ Left arm } & \multicolumn{5}{|c|}{ Right arm } \\
\hline & & & & & \multirow{2}{*}{$\begin{array}{c}\text { Stroke } \\
\text { lenght } \\
\text { avr.(cm) }\end{array}$} & \multicolumn{2}{|c|}{ Force $1[\mathrm{~N}]$} & \multicolumn{2}{|c|}{ Power 1 [W] } & \multirow{2}{*}{$\begin{array}{c}\text { Stroke } \\
\text { lenght } \\
\text { avr.(cm) }\end{array}$} & \multicolumn{2}{|c|}{ Force $2[\mathrm{~N}]$} & \multicolumn{2}{|c|}{ Power 2 [W] } \\
\hline & avr. & max. & avr. & max. & & avr. & max. & avr. & max. & & avr. & max. & avr. & $\max$. \\
\hline \begin{tabular}{|l} 
arithmetic \\
average \\
\end{tabular} & 62,73 & 63,18 & 59,91 & 60,73 & 116,73 & 29,27 & 29,73 & 25,82 & 26,09 & 117,45 & 33,55 & 33,82 & 33,91 & 34,73 \\
\hline $\begin{array}{l}\text { standard } \\
\text { deviation }\end{array}$ & 7,67 & 7,67 & 13,93 & 14,42 & 6,40 & 4,36 & 4,61 & 6,37 & 6,36 & 5,97 & 3,17 & 3,40 & 7,71 & 7,76 \\
\hline median & 63,00 & 64,00 & 57,00 & 58,00 & 115,00 & 30,00 & 31,00 & 25,00 & 25,00 & 116,00 & 33,00 & 33,00 & 32,00 & 33,00 \\
\hline $\min$. & 52,00 & 52,00 & 41,00 & 41,00 & 109,00 & 23,00 & 23,00 & 17,00 & 18,00 & 111,00 & 29,00 & 29,00 & 23,00 & 24,00 \\
\hline max. & 76,00 & 76,00 & 85,00 & 87,00 & 127,00 & 36,00 & 37,00 & 36,00 & 37,00 & 128,00 & 39,00 & 40,00 & 49,00 & 50,00 \\
\hline var. & 24,00 & 24,00 & 44,00 & 46,00 & 18,00 & 13,00 & 14,00 & 19,00 & 19,00 & 17,00 & 10,00 & 11,00 & 26,00 & 26,00 \\
\hline
\end{tabular}


Na základe vyhodnotenia vztahov medzi sledovanými ukazovatelmi v 2. skupine probandiek v teste 2 konštatujeme tesnú závislost’ priemerných a maximálnych hodnôt sily a výkonu, ktorá sa prejavila na $1 \%$ hladine štatistickej významnosti (Tab. 11).

Tabulka 11 Neparametrický Wilcoxonov T-test, 2. skupina (test 2)

\begin{tabular}{|l|l|c|c|}
\hline \multicolumn{2}{|c|}{} & T - test & Sign. \\
\hline & avr. & 0,948 & \\
\hline Force & avr. & $\mathbf{2 , 8 9 0 ^ { * * }}$ & $\mathrm{p}<0,01$ \\
\hline & max. & $\mathbf{2 , 8 9 0 ^ { * * }}$ & $\mathrm{p}<0,01$ \\
\hline Power & avr. & $\mathbf{2 , 9 8 0 ^ { * * }}$ & $\mathrm{p}<0,01$ \\
\hline & max. & $\mathbf{2 , 9 8 0 ^ { * * }}$ & $\mathrm{p}<0,01$ \\
\hline
\end{tabular}

Tabulka 12 Neparametrický Mann-Whitneyov U-test, 2. skupina (test 2)

\begin{tabular}{|c|c|c|c|c|c|c|c|c|c|c|c|c|c|c|}
\hline & \multirow{2}{*}{\multicolumn{2}{|c|}{ Force [N] }} & \multirow{2}{*}{\multicolumn{2}{|c|}{ Power [W] }} & \multicolumn{5}{|c|}{ Left arm } & \multicolumn{5}{|c|}{ Right arm } \\
\hline & & & & & \multirow{2}{*}{$\begin{array}{c}\text { Stroke } \\
\text { lenght } \\
\text { avr.(cm) }\end{array}$} & \multicolumn{2}{|c|}{ Force 1 [N] } & \multicolumn{2}{|c|}{ Power 1 [W] } & \multirow{2}{*}{$\begin{array}{c}\text { Stroke } \\
\text { lenght } \\
\text { avr.(cm) }\end{array}$} & \multicolumn{2}{|c|}{ Force $2[\mathrm{~N}]$} & \multicolumn{2}{|c|}{ Power 2 [W] } \\
\hline & avr. & max. & avr. & max. & & avr. & max. & avr. & max. & & avr. & max. & avr. & max. \\
\hline Test & $3,455^{* *}$ & $3,558 * *$ & $1,832(*)$ & $2,079 *$ & $2,187^{*}$ & $3,459 * *$ & $3,423^{* *}$ & $2,083^{*}$ & $2,329 *$ & $1,763(*)$ & $3,435 * *$ & $3,435 * *$ & 1,623 & $1,767\left(^{*}\right)$ \\
\hline
\end{tabular}

Poznámka: ** $\mathrm{p}<0,01 ; * \mathrm{p}<0,05 ;(*) \mathrm{p}<0,10$

Vyhodnotením výsledkov všetkých sledovaných ukazovatel'ov v teste 2 môžeme konštatovat', že probandky vekovej kategórie juniorky a seniorky dosiahli podla očakávania lepšie výsledky ako probandky vo vekovej kategórii staršie žiačky. Porovnaním výsledkov oboch skupín sme zistili závislost’ sledovaných ukazovatelov: priemerných hodnôt sily a výkonu pri súhre, záberov pravou a lavou pažou a v dížke dráhy záberu pravou pažou na $1 \%$ hladine štatistickej významnosti. Signifikantne ( $5 \%$ hladina štatistickej významnosti) sa prejavil vztah medzi maximálnym výkonom v súhre, dížkou záberu lavej paže, priemerným a maximálnym výkonom lavej paže (Tab. 12).

\section{ZÁVER}

Zo zistených výsledkov sledovaných silových parametrov počas imitovaného prsiarskeho záberu a počas imitovaného záberu pri výpichu (trčenie) sme zaregistrovali vyrovnanú úroveň v rámci oboch vekových kategórií. Dominantnost pravej paže u všetkých probandiek konštatujeme na základe dlhšej dráhy záberu, vyšších hodnôt priemernej a maximálnej sily a výkonu počas imitácie rôznych druhov záberu. Táto skutočnost’ sa môže prejavit v nerovnomerných záberoch pri vykonávaní špeciálnej techniky počas zaujatia jednotlivých polôh (napr. vertikálna poloha strmhlav), ako aj v presunoch pretekárky po sútažnej ploche.

Kedže dobrá úroveň silových schopností paží sa premieta do presnejšej a dokonalejšej realizácie športového výkonu v synchronizovanom plávaní, javí sa predmetné v tréningu venovat pozornost' rovnomernému posilňovaniu oboch paží v suchej príprave. Počas nácviku povinných figúr upriamit pozornost̉ na transfer silovo-rýchlostných schopností paží v zdokonalení techniky záberov. Najlepšie výsledky v staršej vekovej skupine sme zaregistrovali u seniorky B.D. a junioriek K.K, L.M. Tieto juniorky sú členkami reprezentácie a na MEJ v roku 2009 obsadili 12. miesto v tímovej zostave. Na vývojové tendencie rastu sily a výkonu počas záberov paží od starších žiačok po juniorky až seniorky potvrdzujú výsledky korelačnej analýzy, kde sa významnost' rozdielov medzi skupinami prejavila štatisticky významná.

Diagnostikou úrovne silových schopností na plaveckom ergometri sa zatial’ v synchronizovanom plávaní na rozdiel od plávania (Matúš - Macejková, 2009) u nás autori nezaoberali. Sme si vedomí toho, že aktuálnu úroveň silových schopností v synchronizovanom plávaní je dôležité monitorovat’ v dlhodobejšom časovom horizonte a vo väčších súvislostiach. Zistenie podmienenosti výsledkov v kontexte so sútažnou disciplínou, ako i vo vztahu $\mathrm{k}$ hmotnosti a výške synchronizovanej plavkyne. Uvedená štúdia 
naznačuje široké spektrum možností aplikácie tohto zariadenia nielen z dôvodu monitorovania aktuálneho stavu, ale aj ako vhodný tréningový prostriedok rozvoja silovo-rýchlostných schopností pretekárok.

\section{Literatúra}

BOČKAYOVÁ, E.; LABUDOVÁ, J. 2004. Vztah medzi úrovňou telesného rozvoja, pohybovou výkonnostou a športovým výkonom 15-18 ročných synchronizovaných plavkýň. Bratislava: Acta Facultatis Educationis Physicae Universitatis Comenianae. Bratislava: Univerzita Komenského, XLV, 2004.

ČECHOVSKÁ, I.; PESLOVÁ, E. 2007. Nebojte se v plavání využívat sculling: Praha, TVSM 73., č.6, 2007, s. 24-30. ISSN 1210-7689.

COSTIL, D. L., MAGLISCHO, E. W., RICHARDSON, A. B. 1992. Swimming. Handbook of sport medicine and science. Oxford: Blackewell Scientific Publications, 1992, ISBN 0-632-03331-2.

DUVAČ, I.; LABUDOVÁ, J. 2008. Úroveň rovnováhových schopností a špeciálnych vytrvalostných schopností v synchronizovanom plávaní. In: Současný sportovní trénink. Praha: Olympia. ISBN 978-807376-079-3, s. $64-67$.

DOVALIL, J. et al. 2002. Výkon a trénink ve sportu. Praha: Olympia, 2002, s. 96, ISBN 80-7033-760-5. DOLEŽAJOVÁ, L.; LEDNICKÝ, A.2002. Rozvoj koordinačných schopností. Bratislava: SVSTVŠ, 2002. s. 131.

FINA Handbook 2006 - 2009: Lausanne: FINA, 2006.

KASA, J. 2002. Športová antropomotorika. Bratislava: Vysokoškolská učebnica pre študentov telesnej výchovy a športu na VŠ v SR, Univerzita Komenského, Bratislava: 2002, ISBN 80-968252-3-2.

KASA, J. 2006. Pohybové predpoklady a ich diagnostika. Bratislava: FTVŠ UK, 2006. ISBN 80-8075-134-X. LABUDOVÁ, J. 2009. Synchronizované plávanie z pohladu športovej humanistiky. In: Šport a spoločenské a humanitné vedy 2009. Bratislava: ICM AGENCY, 2009. s. 406-411. ISBN 978-80-89257-14-0.

LABUDOVÁ, J.; ZEMKOVÁ, E. 2009. Úroveň rovnováhových schopností synchronizovaných plavkýň a možnosti jej rozvoja [elektronický dokument] In: Vedecké práce 2009. - Bratislava : Slovenská technická univerzita, 2009. - S. 126-131. - ISBN 978-80-227-3095-2 [Vedecké práce 2009. Bratislava, 1.7.2009]

MATÚŠ, I.; MACEJKOVA, Y. 2009. Analýza úrovne silových schopností vo vode a na suchu výkonnostných plavcov. In: Telesná výchova, šport, výskum na univerzitách. Bratislava: Strojnícka fakulta STU, 2009, s. 1-6. ISBN 978-80-227-3210-9.

MORAVEC, R. et al. 2004. Teória a didaktika športu. Bratislava: FTVŠ UK, 2004, ISBN 80-89075-22-3. MORAVEC, R. ; KAMPMILLER, T.; SEDLÁČEK, J. et al. 1996. Eurofit, Telesný rozvoj a pohybová výkonnost’ školskej populácie na Slovensku. Bratislava: SVSTVŠ, 1996, s. 181. ISBN 80-967487-1-8.

OLŠÁK S., 2006. Zborník z konferencie o športovo talentovanej mládeži, Zdravotné a diagnostické oddelenie VŠC Dukla Banská Bystrica, ISBN 80-969522-2-6.

RUŽBANSKÝ, P., 2006. Diagnostika trénovanosti v športovej príprave talentovanej mládeže. In Konferencia o športovo talentovanej mládeži. Bratislava: 2006, s. 22-26. ISBN 80-969522-2-6.

STREITOVÁ, A., 1996. Faktory determinujúce a predikujúce športový výkon v synchronizovanom plávaní. (Dizertačná práca). Bratislava: Univerzita Komenského. FTVŠ, 1996.

Weba Sport Austria [online]. Wien Austria: Swim Ergo Introduction. Posl. úpravy 29.01.2010 [cit. 11.01.2010]. Dostupné na http://www.weba-sport.com/weba/swim ergo.html 